\title{
Youth Subculture of RPG Community: On the Problem of Methodological Description
}

\author{
Sergei M. Kopytin* \\ Khabarovsk Regional Children's Library \\ named after N.D. Navolochkin \\ 25 Leningradskaia Str., Khabarovsk, 680013, Russia
}

Received 05.04.2016, received in revised form 27.04.2016, accepted 18.05.2016

The paper offers an analysis of traditional and contemporary methodological approaches to studying of youth subcultures. The author looks into structural, functional, deviant, hermeneutic, semiotic, sociological aspects; determines their drawbacks in the modern science; makes a conclusion based on the structural, semiotic, phenomenological research of role-playing communities. Such methodology allows describing the interrelations of characteristic structural, semiotic, aesthetic and phenomenological traits of the studied subculture; revealing the connection between structural and semiotic signs of socio-cultural forms of youth subculture on the one hand and subculture identity, the latter defining the meaning and pragmatics of subculture practice.

Keywords: youth subculture, role-playing games (RPG), methodology, subculture practices, subculture identity.

DOI: $10.17516 / 1997-1370-2016-9-6-1480-1489$.

Research area: culture studies.

The transformations taking place in the conditions of socio-cultural crisis, following the decreasing effectiveness of traditional social mobility, with social practices often opposing the declared values, affect the entire society directly and indirectly. However, these changes in particular involve youth communities. There are cases when the socialization of modern youth is carried out beyond the traditional social institutions. While established norms give primary socializing role to the family, educational institutions, professional organizations, and so on, the new approaches should take into account, describe and explain other alternative forms of sociocultural organization of youth.

An example of such forms is youth subcultural communities. Having become a mass phenomenon in the social movements in the wake of the mid $20^{\text {th }}$ century, they naturally turned out to be the subject of serious scholarly attention. Methodology of youth subcultures' research evolved as a reflection of social and cultural non-linear processes occurred in the 1950-1970s. At the moment science was mainly interested in the nature of relations between the subcultures and the "core" culture, so subculture was originally considered in the context of ideas

(c) Siberian Federal University. All rights reserved

* Corresponding author E-mail address: narter16@gmail.com 
about a common norm, only beyond which there were certain subcultural phenomena. However, within a relatively short time there appeared other multiple directions aimed at exploring subcultural phenomena.

Along with the notion of subcultures as a form of deviation (A. Cohen, R. Klauord, L. Oulin, R. Merton, S. Cohen, G. Sykes D. Matza) [Gilinskii] there formed structural and functional understanding of subcultural phenomena, which integrated socio-cultural specificity of subcultures with specific social status of young people [Parsons], [Eisenstadt]. The methods that were currently used for the analysis of socio-cultural phenomena in the works of C. Levi-Strauss, R. Barthes, T. Parsons et al., gave significant results in relation to the new subject. Structural and semiotic representations generally allowed the researchers to explain scientifically the formation, operation and termination processes of the subcultural communities not in relative and aspect, narrow interpretations of deviation, social protest and so on, but in view of the subcultures as sign systems. Subcultural practices were thus understood as specific texts. The study of these texts in their functional sense made it possible to understand characteristic subcultural communities as a form of socio-cultural mechanisms of functioning and transmission of certain functional (pragmatic) values. Structural and functional studies demonstrated the unity of the basic laws operating in the "large" and "small" socio-cultural systems; revealed the functional significance of subcultural practices and, what is more important, their systemic nature.

Successfully overcoming a number of methodological difficulties associated with stigmatization and evaluation, structural and functional approach, however, could not provide answers to all the questions that have arisen in the course of subcultural studies. By focusing on the functional significance of the existence of youth subcultures in the context of the "big" culture and giving general answers, this approach in a sense leveled down the specifics of individual subcultural practices. Features of local cultural phenomena could not be satisfactorily explained solely in terms of the sociological approach. It was also necessary to study the processes of understanding in the subcultural sign systems, the specifics of interpretation regarding subcultural texts. In light of this problem, a special attention should be paid to the way of synthesis of existing approaches with the philosophical issues: the need arose in the hermeneutics of subcultural phenomena. At the fore ground appeared a problem of consciousness of the subculture's subject. Though being earlier implicit, now it questioned the specifics of subcultural worldview, closely associated with the categories of everyday life and the game culture, with the mechanisms of interpenetration of pragmatics and aesthetics.

At the end of the 1960s T. Roszak introduced the concept of counterculture into practice, moving the focus from the sociological to the ideological dimension [Roszak]. In the context of counterculture studies there were also developed ideas about the importance of understanding the world of the game and the aestheticization of everyday life in a socio-cultural organization. The ideologists and researchers studying counterculture (H. Marcuse, J. Dumazedier, M. Dufrenne et al) [Kozhevnikov] did not consider a penchant of countercultural communities for leisure practices as random. In order to adequately describe the countercultural outlook and practices they revised the classic representations of the relationship between art and everyday life, which resulted in the idea of spontaneous, non-institutional, deprofessionalized creativity. M. Dufrenne proposed the idea of creativity in everyday life, which gives the opportunity to express oneself freely in the game and the enjoyment; at the same time this creativity generates a "spontaneous 
ideology", destroying strongly fortified in the traditional socio-cultural relations mechanisms of exclusion and suppression [Dufrenne]. S.B. Kozhevnikov believes that the driving force behind the youth movements of the 1960s were not so much political as aesthetic reasons. At the heart of this revolt, according to the researcher, there also lay the game basis, as its goal was to "demonstrative opposition ... between themselves and their values to the public values", rather than "real curtailment of social institutions" [Kozhevnikov].

Wide area of subcultural studies, which includes the work of R. Hogarth, S. Hall, T. Jefferson, G. Manghem, J. Pearson, D. Hebdige, P. Willis, J. Clark, D. Downes, A. McRobbie etc., was developed in the UK on the basis of the sociology of directions, attributing the behavioral characteristics to a certain class environment. The emergence of a single interdisciplinary field "cultural studies" was due to the creation of the Birmingham Center for Cultural Studies, which was later transformed into the Department of Cultural Studies and Sociology of the University of Birmingham. The theoretical basis of the new school were the methods developed within the framework of cultural anthropology, as well as approaches that emerged in the course of studying the actual socio-cultural problems: the media specifics, phenomenon of the mass culture and the "consumer society", sexual behavior, ethnic and gender movements, and so on. In addition to these theoretical foundations of "cultural studies" school, or the "Birmingham School" we should mention ideas of C. Marx, which British sociologists perceived in a modernized version (for example, they perceived the notion of hard determinismbetween "base" and "superstructure" critically).

The main challenge facing the "Birmingham School" was the problem of identity in today's social reality, while the basic methodological premise was a view of the total multiplicity of contemporary culture (racial, ethnic, class, etc.) and the principle of multiculturalism. In other words, the original task of the Birmingham Center for Cultural Studies was to study the contemporary culture of everyday life in the context of fundamental social laws. A characteristic feature of the new school was its attention to the less known marginal phenomena which, however, actually make up a large part of social and cultural everyday life of any contemporary individual.

The variety, variability and non-linear systematic character of the modern subcultural environment led foreign experts to express a natural desire to find a new methodology to describe satisfactorily the complex picture. The unifying foundation of modern Western "post-subculture" research is a critical attitude towards heritage of the "Birmingham School" [Muggleton, Weinzierl]. Critics particularly emphasize that the complex and volatile nature of the current youth culture cannot be adequately described by linear representations. Critics also exposed the inability of the Birmingham model to give a reliable forecast for the development of youth subcultures.

In alternative "post-subculture research" there can be traced two main directions today. They do not exclude each other, as the first of these involves the modernization of the methodology, formed in the writings of the "Birmingham School", while representatives of the second direction of "post-subculture" research go even further, actually renouncing the term "subculture". The result of these efforts was the emergence of new concepts of youth sociocultural formations. On the other hand, there were made marked attempts to preserve the old ideas, supplementing them with the necessary concepts. Terminological and methodological diversity that inevitably arises as a result of these investigations 
provoked attempts of differentiation and systematization of new ideas in the 2000s. They were believed to be based either on aspectual distinction, or on correspondence to some form of youth culture, for which the most appropriate term should be chosen.

In the Russian tradition, despite the relatively late start in studying subcultures, there was a significant number of studies of subcultural phenomena. The researchers include T.B. Shchepanskaia, L.V. Shabanov, E.L. Omel'chenko, V. A. Lukov, E.A. Medvedev, A.N. Erokhina, D.B. Pisarevskaia et al. Although the sociological and pragmatic perspective continues to determine the direction of a wide range of research, these scientific approaches have recently been reproached for their insufficient and transitional nature. Sharing this point, we shall note that the subcultural phenomena can be described not only in narrowly specific terms of positive sociology, psychology and pedagogy, but also in the context of the fundamental cultural patterns. Better understanding of subcultures and their role in cultural processes allows us to study them as a special form of organization of consciousness. The next studies should investigate philosophical and aesthetic conditions of the existence of subcultures and their ideological specificity.

The method to address these theoretical difficulties concerns synthetic models based on phenomenological and hermeneutical grounds. Taking into account the already accumulated experience, subculture shall not be considered as formations, clearly opposed to "culture". The opposition of culture and subculture is largely paradigmatic. The so-called "protest", "countercultural" or "escapist" side of subcultures is not so much in opposition to the "official" cultural system, but a way of forming "areas of meaning" in terms of lack of value and meaning. So solution to cognitive problems shall be found not in the way of finding "hard" conceptual foundation, but on the contrary, through the study of the phenomenon of the border, the threshold condition.

Dialogue character found in sentinel works by M.M. Bakhtin, Yu.M. Lotman et al. is evident not only in the historical existence, but also in the internal structure of culture. Any cultural epoch is a complex conglomerate of disparate meanings, trends and manifestations of spiritual life. From this position, the subculture can be represented as a specific historical form of culture's synchronic dialogism. However, this position is often reduced at best to the general declarations. Particular subcultural phenomena, the elements of subcultural communities and sustainable features of subcultural practices are usually described outside the dialogical context.

Attention to the cognitive aspect of subcultural research sharpens the question about the nature of subcultural identity. Despite the presence of a certain number of works, scrutinizing ideological issues of subcultures, today the issue of connection between subcultural identity and certain forms outlook has not been fully clarified. The researchers have not worked out the issue of socio-cultural mechanisms of formation, functioning and transfer of subcultural identity.

Currently, the traditional forms of identity undergo a crisis [Astier]. The weakening of the classical forms of "big" identity goes along with the strengthening of its local forms. Marginalized young people's position in the post-industrial culture implies specific youth identity. The identity of a modern young man, coinciding in its "big" form with the identity of the "big" communities must display certain differences at the local level, including ones in the subcultural communities. Understanding identity as a fact of consciousness, objectified in social experience (in the form of relatively stable structures) and in unique personal experience, we are able to study 
the relationship between the sustainable forms of subcultural practice and subcultural worldview, avoiding recourse to stable stereotypes that continue extensive existence in scientific works and are securely retained in the minds of the professional and the general public, getting into the practical activity of teachers, social workers, media representatives and others.

Complex application of structural, semiotic, hermeneutic and phenomenological methods allows us to describe the relationship of characteristic structural and semiotic, aesthetic and phenomenological traits of the studied subcultures, overcoming the incompleteness, stereotypical and widespread fragmentation of the current approaches in relation to the subcultural research. Methodologically consistent application of the fundamental methodology, "bringing it down" from the level of high abstraction to the specific social cultural phenomena offers a possibility to refine the structure and functions of socio-cultural forms of a particular youth subculture, as well as to clarify their role in the formation and functioning of the identity of today's young people.

Given the experience of the existing subcultural studies and the experience of direct observation of subcultural phenomena, we conducted a study of a number of specific features of the Russian youth subculture that have arisen in the community of role-playing games (RPG community). The object of our study was the youth subculture of the role-playing games community; the subject of study was social and cultural forms of subculture in the role-playing games community. The studied forms included role-playing game as a specific form of leisure and creative activities (the central form of subcultural practices of the community); the forms of daily subcultural organization and communication; the codes of space and time, naming, control and power, as well as different interpretations of these codes (situational, everyday, mythological and deterministic).

The aim of our study was to disclose the links between structural and semiotic features of the existing and observable socio-cultural forms of youth subculture (on the example of subculture in the RPG community) and subcultural identity, defining the meaning and pragmatics for subcultural practice.

Achieving the aim of the study we defined a number of specific objectives:

1) to examine and analyze critically the basic methodological approaches to the study of youth subcultures in the western tradition;

2) to study the history of Russian research of youth subcultures as an object of sociohumanitarian analysis;

3) to identify the main socio-cultural characteristics of the community of role-playing games and describe existing approaches to the study of the community;

4) to make an analysis of the structural and semiotic specificity of a role-playing game;

5) to reveal the hermeneutical features of a role-playing game, explicating the the relation of the role-playing game semiosis with the semiosis of art;

6) to clarify the definition of subcultural identity and its relationship with everyday forms of subcultural practice;

7) to analyze the structure of the RPG community as a group community (basic subculture);

8) to characterise the main forms of social organization in the local RPG community and create a typology of these forms;

9) to consider the semiotic processes of encoding and interpreting as a way of formation and transmission of subcultural identity in the RPG community.

The theoretical and methodological basis of research includes methods of overt (participant) 
observation and non-participant observation used to fix the historical and contemporary forms of subcultural practice in the RPG community. Participant observation was used in relation to Khabarovsk RPG community in the period from 2002 to the present time. Non-participant observation was applied to RPG communities in Khabarovsk, Vladivostok, Irkutsk, Novosibirsk, Krasnoyarsk, St. Petersburg, Moscow and the Moscow Oblast in the period from 1990 to the present time. In addition to observation, we applied the descriptive method in order to present features of historical and contemporary forms of subcultural practices on youth communities; the structural-semiotic method - to analyze the structure and semantics of a particular sign system, which is a set of socio-cultural forms of subcultural practice in the role-playing games communities, such as a role-playing game as a central form of this practice (culture semiotics by Yu.M. Lotman, the doctrine of the chronotope by M.M. Bakhtin, socio-pragmatic analysis of T.B. Shchepanskaia). To study the diachronic variability of socio-cultural forms of subcultural practice in the RPG community we used the comparative-historical method. Specific features of semiosis of a role-playing game and its relationship with the semiosis of art were proved with the help of the hermeneutic method (M.M. Bakhtin, Yu.M. Lotman). The phenomenological method was of advantage in establishing the role of socio-cultural forms of subcultural practice in the formation of a specific subcultural identity, as well as the interpretation of the main forms of subcultural worldview, characteristic of this community.

Having shed the light on the definition of a role-playing game as a specific form of leisure and creative activity, accumulating a particular subcultural community around; having found that the role-playing game is far from daily RPG practice, we focused on the fact that apart from the role-playing game one should distinguish others extrinsic (concerning the game itself) socio-cultural game forms, which are inherent in this community. It is needless to say that scientific papers on the subject have not usually taken into account this matter. Based on direct experience of participation in the subcultural practice of the RPG community and many selfreflexive materials provided by the community, we produced a comprehensive structural and semiotic analysis of the role-playing game as a center of social and cultural form of subculture in the RPG community. In addition, referring to the aesthetic doctrine by M.M. Bakhtin [Bakhtin], we have given the hermeneutic interpretation of some aspects of the preparation, organization, process and the final assessment of the role-playing game from the standpoint of its main agents - players and masters.

Our procedures yielded a number of conclusions about the semiotic nature of the role-playing game, a variety of methods and principles of the landmark simulation in the game, and the essential link of the game structure and the sign forms used with aesthetic, pragmatic and axiological attitudes of its organizers and participants. Also, we have found that the participants and organizers of the roleplaying game are guided by complex ethical, cognitive and aesthetic motifs that reflect the complex ethical and aesthetic nature of the roleplaying game, which distinguishes it from the similar (and, moreover, the namesake) forms of activity.

Next, clarifying and specifying the widely used concept of identity, we have consistently applied it to specific subcultural self-identity. Having investigated a number of everyday sociocultural forms of specific subcultures as tools of construction, maintenance and operation of subcultural identity, we have explained some essential aspects of daily subcultural practice 
in the RPG community. Phenomenological understanding of subcultural identity has allowed us to represent this practice as a process of construction and expression of a specific worldview. The special features of this worldview (and related socio-cultural forms) include its: 1) fundamental incompleteness, complementarity; 2) "constructive", "created" character; 3) antinomy, presence of fundamentally different (mythological, ironical, deterministic, everyday situational) elements in its structure (forming howeveran organic unity). Theseresults generalize and improve fragmentary, incomplete and often implicit ideas about the role of worldview in the forms of subcultural practices accessible to direct observation.

The study of the complex of particular subcultural phenomena, characteristic of the role-playing games community allowed us to draw some conclusions about the relationship of structural and semiotic specificity of subcultural practices with subcultural worldview and identity:

1. The development and operation of subcultural communities do not depend solely on direct borrowing during any direct contact. Closeness and unity of subcultural communities are increasingly determined by common understanding of the world, rather than by diffusion processes.

2. Socio-cultural forms of youth subcultures are specific structural and semiotic units, through which there forms a special phenomenological structure - subcultural identity. Subcultural identity has a dual character: it is often constructed and functions in informal, including the game modes. At the same time as a phenomenon and a social determinant this subcultural identity is quite "serious" and diachronically stable (since it is translated into subcultural "generation" by the means of the special sign systems). Thus, it detects not as much contrastive, but rather complementary character as regards the traditional forms of identity (ethnic, national, etc.).

3. The observed rootedness of subcultural identity in the broader socio-cultural contexts shows that a subculture is not isolated from a "normal" or "core" culture, being a part of a wide range of cultural contexts and dialogical relations.

4. Socio-cultural forms of youth subculture that cause the construction, operation and transfer of subcultural identity are a complex, heterogeneous system, uniting various practices and organizing daily life of the subculture participants at different levels. Nondiscrimination of the specificity of the particular socio-cultural forms that make up the system (for example, a role-playing game as the event and everyday forms of subcultural practice in the RPG community) in scientific research has led to unjustified generalizations and simplifications that ultimately distort the understanding of the essence of youth subcultures. Functioning and development of local communities are subject to the general laws, demonstrating a certain resemblance to the laws of functioning and development of the larger socio-cultural groups (ethnic groups, nations, and so on).

The undertaken research was aimed at checking the possibility of using an integrated methodology in studying the particular features of the development and existence of youth subcultures. It gives an example of a consistent analytical criticism of a number of stereotypes, steadily associated with the phenomenon of youth subculture, and demonstrates the possibility of correcting the existing views by analyzing the subcultural forms in their specific representations, in the context of their historical development and relations with the phenomena that go beyond subcultural practices. The methods and approaches used in the study may partially satisfy a revealed request 
(in professional publications) for a involving interaction with the representatives of methodologically consistent concept of youth youth subcultures. Summing up, provisions and subcultures, not divergent from the observed materials of this study can be used in teaching practical phenomena. The certain details and cultural and philosophical disciplines, especially results of this study can be used in various in their parts, directly or indirectly related to the forms of analytical, methodical and social work, phenomenon of youth subcultures.

\section{References}

Astier, I.V. (2009). Krizis social'nykh sviazei i problema odinochestva molodezhi v usloviiakh megapolisa. Tekhnologii psikhologo-social'noi raboty $\mathrm{v}$ usloviiakh megapolisa [Crisis of social ties and the problem of youth loneliness in megalopolis conditions. Techniques of psychological and social works in megalopolis conditions], In Materialy mezhdunarodnoi nauchno-prakticheskoi konferentsii [Proceedings of international scientific and practical conference]. Saint-Petersburg, SPbGIPSR, 330 p, 116-120.

Bakhtin, M.M. (1975). Formy vremeni i khronotopa v romane. Ocherki po istoricheskoi poetike Voprosy literatury i estetiki [Forms of time and khronotope in novel. Essays on historical poetics. Issues of literature and aesthetics]. Moscow, Khudozh. Literatura, 234-407.

Bakhtin, M.M. (2000). Avtor i geroi v esteticheskoi deiatel'nosti. Avtor i geroi: K filosofskim osnovam gumanitarnykh nauk [The author and a character in aesthetic activity. The author and a character: On the philosophical foundations of the humanities]. Saint-Petersburg, Azbuka, 336 p.

Clarke, J. (1993). The Skinheads and the Magical Recovery of Community, In S. Hall and T. Jefferson (eds) Resistance Through Rituals: Youth Subcultures in post-war Britain. London, Routledge, 99-102.

Downes, D. (1966). The Deliquent Solution. A Study in Subcultural Theory. London: CollierMacmillan, $284 \mathrm{p}$.

Dufrenne, M. (1973). Iskusstvo i politika [Art and politics], In Voprosy literatury [Issues of literature], 4, 111.

Eisenstadt, S.N. (1956). From Generation to Generation: Age Groups and Social Structure. Glencoe, Illinois, The Free Press, 357 p.

Erohina, N.N. (2006). Sociosemioticheskie osnovy molodezhnoi subkul'tury [Sociological foundations of youth subculture]. Dis. ... kand. sociol. nauk: 22.00.06. [Dissertation of Candidate of Sociological Sciences]. Tambov, $153 \mathrm{p}$.

Gilinskii, Ia. (2004). Deviantologiia: sociologiia prestupnosti, narkotizma, prostitutsii, samoubiistv i drugikh "otklonenii" [Deviantology; sociology of crime, drug addiction, suicide and other "aberrations']. Saint-Petersburg, Iuridicheskii Tsentr Press, 520 p.

Hall, S., Jefferson, T. (eds). (2006). Resistance through Rituals. Milton Park, Routledge, 252 p.

Hebdige, D. (1979). Subculture: The Meaning of Style. London, Methuen.

Hoggart, R. (1957). The Uses of Literacy: Aspects of working-class life with special reference to publications and entertainments. London, Harmondsworth, Penguin; Chatto and Windus, $320 \mathrm{p}$.

Kozhevnikov, S.B. (2004). Estetizatsiia povsednevnosti v ideologii kontrkul'tury [Aesthetization of everyday life in the ideology of counter-culture], In Sotsiologicheskii zhurnal [Sociological journal], $3-4$. 
Lukov, V.A. (2007). Molodezhnye subkul'tury v sovremennoi Rossii [Youth subcultures in modern Russia]. M., Informatsionnyi gumanitarnyi portal "Znanie. Ponimanie. Umenie”. Available at: http:// www.zpu-journal.ru/gum/new/articles/2007/Lukov_Val/4/

McRobbie, A. (1991). Feminism and Youth Culture. From Jackie to Just Seventeen. London, Macmillan.

Medvedev, E.A. (2004). Subkul'tura uchastnikov rolevykh igr i metody issledovaniia ee vozdeistviia na lichnost' [Subculture of role-playing games participants and research methods of its impact on personality]. Dis. ... kand. sociol. nauk: 22.00.06. [Dissertation of Candidate of Sociological Sciences]. Moscow.

Muggleton, D., Weinzierl, R. (2003).The Post-subcultures Reader. New York, Berg.

Mungham, G., Pearson, G. (eds). (1976). Working Class Youth Culture. London, Routledge \& Kegan Paul.

Omel'chenko, E.L. (2000). Molodezhnye kul'tury i subkul'tury [Youth cultures and subcultures]. Moscow, RAS, Institute of Sociology, 262 .

Parsons, T. (1965).Youth in the Context of American Society, In Ericson, Eric (eds). The Challenge of Youth. New York, Basic Books.

Pisarevskaia, D.B. (2009). Fenomen subkul'tury rolevykh igr v sovremennom obshhestve [A phenomenon of subculture of role-playing games community in the modern society]. Avtoreferat dis. ... kandidata istoricheskikh nauk: 07.00.07. [Thesis of Dissertation of Candidate of Sociological Sciences]. Moscow, $28 \mathrm{p}$.

Roszak, T. (1995). Making of a Counter Culture: Reflections on the Technocratic Society and Its Youthful Opposition. Berkeley: University of California Press, 310 p.

Shabanov, L.V. (2005). Social'no-psihologicheskie kharakteristiki molodezhnykh subkul'tur: social'nyi protest ili vynuzhdennaia marginal'nost' [Social and psychological characteristics of youth subcultures: social protest or impelled marginality]. Tomsk, Tomsk State University, 399 p.

Shhepanskaia, T.B. (2004). Sistema: teksty i traditsii subkul'tury [System: texts and traditions of subculture]. Moscow, OGI, $286 \mathrm{~s}$.

\section{Молодежная субкультура сообщества ролевых игр: проблема методологического определения}

С.М. Копытин

Хабаровская краевая детская библиотека им. Н.Д. Наволочкина Россия, 680013, Хабаровск, ул. Ленинградская, 25

В статье дается анализ традиционных и современных методологических подходов к исследованию молодежных субкультур (структурно-функииональный, девиантный, герменевтический, семиотический, сочиологический и др.), определяются причины их недостаточности в сегодняшней научной практике. Автор предлагает результаты проведенного исследования сообщества ролевых игр, основанного на комплексном применении структурносемиотического, герменевтического и феноменологического методов. Такая методология позволяет описать взаимосвязь характерных структурно-семиотических, эстетических 
и феноменологических черт изучаемой субкультуры, раскрыть связи между структурносемиотическими особенностями социокультурных форм молодежной субкультуры и субкультурной идентичностью, определяющей смысл и прагматику субкультурной практики.

Ключевые слова: молодежная субкультура, ролевые игры, методология, субкультурные практики, субкультурная идентичность.

Научная специальность: 24.00.00 - культурология. 